International Journal of Instruction e-ISSN: 1308-1470 • www.e-iji.net

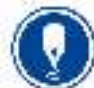

Article submission code: 20200401143355
Received: 01/04/2020 Revision: 25/09/2020
April 2021 • Vol.14, No.2

p-ISSN: 1694-609X

pp. $443-460$

Accepted: 18/10/2020

OnlineFirst: 26/01/2021

\title{
The Impact of Collaborative Learning on Learners' Critical Thinking Skills
}

\section{Idi Warsah}

Institut Agama Islam Negeri Curup, Indonesia, idiwarsah@gmail.com

\section{Ruly Morganna}

Institut Agama Islam Negeri Curup, Indonesia, rulymorganna@gmail.com

\section{Muhamad Uyun}

Universitas Islam Negeri Raden Fatah Palembang, Indonesia, muhamaduyun_uin@radenfatah.ac.id

\section{Hamengkubuwono}

Institut Agama Islam Negeri Curup, Indonesia, hamengku7@ gmail.com

\section{Muslim Afandi}

Universitas Islam Negeri Sultan Syarif Kasim Riau, Indonesia, muslim.afandi@uinsuska.ac.id

$$
\begin{aligned}
& \text { A wide range of studies have examined the impact of collaborative learning (CL) } \\
& \text { on critical thinking skills in various learning subjects. However, very few of them } \\
& \text { are conducted in the field of Islamic education. Thus, the current study aimed at } \\
& \text { examining the impact of CL on learners' critical thinking skills in addressing } \\
& \text { Islamic radicalism as well as their critical thinking retention. Subsequently, this } \\
& \text { study also investigated learners' perspectives on CL. A mixed method approach } \\
& \text { was applied. } 40 \text { learners, } 18 \text { male and } 22 \text { female learners, from an Islamic } \\
& \text { education department at a university in Bengkulu, Indonesia, were engaged as the } \\
& \text { samples of experimentation, and } 9 \text { of them were purposively selected to be the } \\
& \text { participants for the purpose of a qualitative investigation. The quantitative data } \\
& \text { were analyzed using paired sample t-test and independent sample t-test, and the } \\
& \text { qualitative data were analyzed using an interactive model of analysis. The findings } \\
& \text { revealed that CL had a positive and significant impact on learners' critical thinking } \\
& \text { skills. CL also supported the retention of their critical thinking skills. } \\
& \text { Subsequently, the learners perceived that CL was contributive to their emotional } \\
& \text { awareness, learning motivation, cognitive development, and broad-mindedness. } \\
& \text { Grounded in the current findings, further studies can proceed to construct a } \\
& \text { theoretical CL model which incorporates components such as critical thinking, } \\
& \text { learning motivation, cognitive development, and social competence. }
\end{aligned}
$$

Keywords: collaborative learning, critical thinking skills, learning, skills, learners

Citation: Warsah, I., Morganna, R., Uyun, M., Hamengkubuwono., \& Afandi, M. (2021). The Impact of Collaborative Learning on Learners' Critical Thinking Skills. International Journal of Instruction, 14(2), 443-460. https://doi.org/10.29333/iji.2021.14225a 


\section{INTRODUCTION}

In the field of Islamic education in Indonesia, the issues pertinent to Islamic radicalism are becoming a hot and important learning material at the level of tertiary education. This case stems from Indonesian political discourses which continuously address Islamic radicalism issues (Suyanto, Sirry, \& Sugihartati, 2019; van Bruinessen, 2002). The term Islamic radicalism, albeit having no definite consensus and tending to be concerned with a mere political judgment, is associated with Islamic groups that do not agree with democracy and make efforts to change Indonesia into a caliphate (Hadiz, 2008). The Islamic groups as such commonly perceive that Islamic teachings must literally rest upon Qur'an and Sunnah without any interpretation regardless of any condition, and these groups will negatively react to the generally agreed Islamic teachings that pervade amid Indonesian people (Fealy, 2004). Although the existence of Islamic radicalism in Indonesia does not clearly seem to represent violent acts, the so-called pseudoradicalism or Islamic radical ideologies seem to spread vastly amongst Indonesian youth especially in the circle of universities (Suyanto et al., 2019).

In addition to being politicized often, pseudo-radicalism per se potentially prompts Muslims to be intolerant of differences in terms of both religious and cultural diversities (Bruinessen, 2013; Lindsey \& Pausacker, 2016; Menchik, 2016; Warsah, Masduki, Daheri, \& Morganna, 2019), in the meantime Indonesian people as a whole are multicultural (Idris, 2020; Morganna, Sumardi, \& Tarjana, 2020) and multi-religious (Warsah et al., 2019). Thus, de-radicalization efforts are indeed necessary to be made in tertiary learning processes for the sake of leading learners to be broad-minded in the sense of being more tolerant of differences and to able to enhance their skills in the aspects of cognition, metacognition or self-regulated learning, social, and emotion in dealing with Islamic radicalism. As the foregoing, in the aspect of cognition, learners are able to apply various levels of thinking and to think reflectively. In the aspect of metacognition, learners are able to plan, regulate, conduct, and evaluate their own learning strategies. In aspect of social, learners are able to establish good social interactions and relationships. In the aspect of emotion, learners are able to control their emotions while coping with conflicts or differences. One of the de-radicalization efforts that seem effective is to apply collaborative learning (hereafter as CL) in Islamic education classrooms. Embedding CL into learning processes in this way can be categorized as a preventive strategy. It aligns with Riany et al. (2018) who support preventive strategies as a way of de-radicalization.

$\mathrm{CL}$ is a learning strategy wherein two or more individuals are cooperatively engaged in a learning process. In this regard, among individuals within a learning group, they interact, negotiate to solve problems during learning, make use of their cognitive and metacognitive skills during interactions, and become responsible for their learning (Chatterjee \& Correia, 2020; Hautala \& Schmidt, 2019; Kaendler, Wiedmann, Rummel, \& Spada, 2015; Ruys, Van Keer, \& Aelterman, 2014; Ruys, Van Keer Hilde, \& Aelterman Antonia, 2011; Shi \& Liu, 2013). Therefore, interactions are the key to CL. There are two kinds of interactions in CL, namely cognitive interactions in that learners will be actively involved in the processes of thinking, reasoning, analyzing, and 
elaborating with one another concerning the learned material. The other kind is socioemotional interactions whereby learners will understand each other, complete their competences, be empathetic, and feel the essence of their collaborations with each other (Hei, Strijbos, Sjoer, \& Admiraal, 2015; Isohätälä, Näykki, \& Järvelä, 2019). In a wider perspective, Chatterjee and Correia (2020) explain that CL develops learners' interactive competences in a range of dimensions such as affection, cognition, social, and metacognition. The broad concept of CL makes it unlimited to certain rules of learning because active interactions can be made in many ways. In brief, various learning acts such as asking each other, discussing, explaining to each other, debating, and being actively engaged in knowledge construction processes are categorized into CL (Ruys et al., 2014).

There are five important elements oriented towards the application of CL. They comprise direct interaction, positive interdependence, responsibilities, social skills, and learning evaluation (Ruys et al., 2011). Subsequently, the extent of CL activities is central to communicating, dealing with conflicts, solving problems, and making decisions (Valdes-Vasquez \& Clevenger, 2015). In implementing CL, the teacher is expected to be adequately masterful at CL-related theories, strategies, and practices (Weinberger \& Shonfeld, 2018). Anchored in scientific reviews made by Kaendler et al. (2015), there are five competences a teacher needs to master in order to be able to apply $\mathrm{CL}$ in the classroom. They are the competences of devising, controlling, promoting, consolidating, and reflecting on learners' interactions. In addition, learners' competences refer to their abilities to collaborate, do cognitive learning activities, and carry out metacognitive learning activities.

Many of prior studies have proven that CL is contributive to learners' development and their learning success. CL has a positive impact on the processes of learners' cognitive learning (Chee, Yahaya, \& Ibrahim, 2018; Fawcett \& Garton, 2005), their social and emotional functions (Tolmie et al., 2010), and their psychological development (Marzano, Pickering, \& Pollock, 2001). CL consolidates learners in terms of improving their attention to learning, building up their positive attitudes towards learning, motivating them to learn, encouraging them to learn continuously, increasing their learning results, and promoting them to reach good academic achievements (Hei et al., 2015; Giannakos \& Darra, 2018; Kurniasih, Sujadi, \& Pramesti, 2016; Loes, An, Saichaie, \& Pascarella, 2017; Sujito et al., 2019). CL is also predictive to learners' literary development (Kirschner, 2004), leading learners to be open-minded about diversities, and supporting learners' equity (Loes, Culver, \& Trolian, 2018; Shah \& Lewis, 2019).

Furthermore, an array of studies have revealed evidence that CL has a positive effect on the improvement of learners' critical thinking skills (Hunaidah, Susantini, Wasis, Prahani, \& Mahdiannur, 2018; Kusumawati, Hobri, \& Hadi, 2019; Lee, Kim, \& Kim, 2014; Saiz Sanchez, Fernandez Rivas, \& Olivares Moral, 2015; Sulisworo \& Syarif, 2018). Some experts, to name a few Abrami et al. (2008); Howard, Tang, and Austin, 2015; and Ünsar and Engin (2013), define critical thinking skills as thinking processes done by making use of one's knowledge and reflective experiences as maximally as 
possible. Such thinking processes support someone to be capable of explaining a problem, comprehending the interrelationships between a problem and other related elements, analyzing as well as confirming facts associated with a problem, drawing a relevant and representative conclusion so that a problem can finally be solved, and making some proper decisions of what to do further. In line with the aforesaid nature of critical thinking, Asay and Curry (2003) viewed that critical thinking covers scientific thinking processes which extend to identifying and defining an issue, garnering information to learn the issue in depth, analyzing situations with respect to the issue, generating potential solutions of the addressed issue, and evaluating the proposed solutions.

Thus far, there have been several models of critical thinking often adopted by many researchers, and the rubrics of those models are employed to assess learners' critical thinking skills. Among many models, to name a few, the first is Huba and Freed's (2000) model. In brief, the extent of this model covers some elements such as issue identification, understanding general facts of an issue, garnering information, identifying values, generating possible solutions and considering both positive and negative effects of the solutions, choosing the most appropriate solution, determining the ideal actions as regards the generated solution, and drawing conclusions. In their study, Asay and Curry (2003) recommended that this model be used by virtue of its detailed rubrics which can be employed to measure critical thinking skills in terms of problem solving abilities. The second is Paul and Elder's (2008) critical thinking model. In short, this model possesses a number of elements such as goal identification, issue questioning, issue interpretation, concept understanding, generating assumptions, and comprehending implications as well as the related effects. However, Leist, Woolwine, and Bays (2012) recommended that this model be adopted in assessing learners' critical thinking skills in terms of their literary receptive ability on account of this model designed to assess higher students' reading comprehension. The third is Browne, Hough, and Schwab's (2009) model whose aspects encompass stakeholder identification, content interpretation, evidence evaluation, assumption analysis, main feature explanation, and construct proposition. They applied this model in tandem with applying a scaffolding approach to foster learners' critical thinking skills.

It is clear that the essence of critical thinking skills is to consolidate learners to solve problems brought in a learning process. An authentic social problem such as Islamic radicalism in Indonesia, when brought into collaborative classroom discussions in Indonesian Islamic education, can be an ideal learning condition to enhance learners' critical thinking skills. This way also becomes one of the effective efforts made to help Indonesian youth to become more open-minded and to be able to protect themselves from being provoked. Anchored in the scientific consensus as highlighted above, it can be drawn that CL promotes critical thinking which can develop students' potential to solve problems. Thus, the present study is undertaken with two purposes: First, to examine CL's impact on learners' critical thinking skills in addressing Islamic radicalism as well as to see the retention of their critical thinking skills; and second, to investigate learners' perspectives on CL. Resting upon the aforesaid purposes, the following research questions are formulated. 


\section{Research Questions}

1. Does CL have an impact on learners' critical thinking skills in addressing Islamic radicalism?

2. If CL has an impact on learners' critical thinking skills in addressing Islamic radicalism, to what extent is the retention of their critical thinking skills?

3. What are learners' perspectives on CL?

\section{METHOD}

The present study applied a mixed method approach in Islamic education classrooms at a university in Bengkulu, Indonesia. An explanatory mixed-method design (Ary, Jacobs, Sorensen, Walker, \& Razavieh, 2010; Creswell, 2007) was adopted in a way that this study was initiated by conducting quantitative experimentation, and the experimentation data were further supported and explained by the findings of a qualitative study undertaken subsequently. Two purposes were formulated. First, it examined the impact of CL on learners' critical thinking skills in addressing Islamic radicalism by conducting a quasi-experimental method. Second, it qualitatively investigated learners' perceptions of CL. The rationale beyond the application of a mixed method study was to reveal both generalizable data with respect to CL's impact on critical thinking skills as well as to support the existing findings in this context, and at some point to gain in-depth data representing the natural conditions taking place in the study field.

For the experimental purpose, drawing upon a control-group pretest-posttest design, 40 learners, 18 male and 22 female learners, from an Islamic education department were engaged as the participants. They were selected from a population of 100 students by considering their homogenous characteristics such as ages, skills of interaction, and previous academic achievements viewed from GPAs. For the distribution of the 40 learners, 16 learners had high GPAs; 14 learners were considered moderate in their GPAs; and other 10 learners had low GPAs. 20 learners representing the three categories of GPAs were grouped in the experimental class, and in the same way, other 20 learners were grouped in the control class. Learners in both classes were equal in terms of ages, skills of interaction, and academic achievements. Learners in the experimental class were given CL interventions in the form of group discussions addressing various issues of Islamic radicalism in Indonesia. The CL learning procedures were adopted from reasoning elements recommended by Paul (2000). Those of the control class were given common learning interventions in the form of lecturing wherein the lecturer deductively taught learners the materials concerning Islamic radicalism in Indonesia. The two classes undertook their respective interventions for eight meetings. Table 1 below displays the learning steps of both classes for one meeting. 
Table 1

CL and Lecturing procedures

\begin{tabular}{|c|c|c|c|}
\hline $\begin{array}{l}\text { CL } \\
\text { steps }\end{array}$ & Detailed activities in the experimental class & $\begin{array}{l}\text { Lecturing } \\
\text { steps }\end{array}$ & $\begin{array}{l}\text { Detailed activities } \\
\text { in the control } \\
\text { class }\end{array}$ \\
\hline Step 1 & $\begin{array}{l}\text { Learners discuss with one another to identify the } \\
\text { given issue or topic related to Islamic radicalism in } \\
\text { Indonesia. Subsequently, they identify some } \\
\text { general facts related to the topic. }\end{array}$ & Step 1 & $\begin{array}{l}\text { Material } \\
\text { presentation from } \\
\text { the lecturer. }\end{array}$ \\
\hline Step 2 & $\begin{array}{l}\text { Learners are asked to access online libraries or } \\
\text { journals to find literature or studies addressing the } \\
\text { given topic as many as possible by using their } \\
\text { mobile phones or laptops. They keep discussing } \\
\text { any literature they find. However, learners are not } \\
\text { allowed to access information from social media } \\
\text { since the credibility of radicalism-related } \\
\text { information obtained from social media cannot be } \\
\text { guaranteed, and such information to some extent } \\
\text { even triggers radicalism (Behr, Reding, Edwards, } \\
\text { \& Gribbon, 2013). Thus, to guarantee the quality } \\
\text { of information and to avoid getting radicalism- } \\
\text { driven information, students are instructed to } \\
\text { access information from online libraries or journals } \\
\text { providing literature or studies related to the } \\
\text { learned topic. }\end{array}$ & Step 2 & $\begin{array}{l}\text { Interactions in the } \\
\text { form of questions } \\
\text { and answers } \\
\text { between the } \\
\text { lecturer and } \\
\text { learners. }\end{array}$ \\
\hline Step 3 & $\begin{array}{l}\text { Learners are asked to discuss the possible solutions } \\
\text { of the problems existing in their topic by making } \\
\text { use of their knowledge acquired from current } \\
\text { information or literature they get already. }\end{array}$ & Step 3 & $\begin{array}{l}\text { Summary } \\
\text { generation } \\
\text { provided by the } \\
\text { lecturer. }\end{array}$ \\
\hline Step 4 & $\begin{array}{l}\text { Learners continuously discuss to formulate one } \\
\text { best solution by taking account of various realistic } \\
\text { conditions in the context of Indonesian society. }\end{array}$ & & \\
\hline Step 5 & $\begin{array}{l}\text { Learners are asked to propose some ideal actions } \\
\text { to be done in line with their proposed solution. }\end{array}$ & & \\
\hline Step 6 & $\begin{array}{l}\text { Learners reach an agreement to conclude their } \\
\text { collaborative learning results. }\end{array}$ & & \\
\hline
\end{tabular}

To measure the impact of CL on learners' critical thinking skills in addressing Islamic radicalism in Indonesia, an instrument in the form of an essay writing test was assigned for garnering students' critical thinking data in the sections of pretest, posttest, and delayed posttest. An essay test using Indonesian language was considered effective in assessing learners' critical thinking skills especially in an effort to generate solutions of social problems such as Islamic radicalism brought in the current study. Before CL interventions in the experimental class and lecturing interventions in the control class were given, those of both classes were given an essay pretest asking them to propose a solution of a given problem pertinent to Islamic radicalism. After eight meetings of CL and lecturing interventions were done, a posttest having the same characteristics as pretest was given to the learners of both classes. In addition, after one month, a delayed 
posttest was given to the learners of both classes for the sake of viewing their critical thinking retention.

To assess learners' critical thinking skills based on their essays, Huba and Freed's (2000) critical thinking rubric was adopted. This rubric was considered relevant in the current study context in light of that it measured critical thinking skills in terms of solving social problems. Before the essay test was deployed to garner the pretest, posttest, and delayed posttest data, both validity and reliability of the test were processed. Since it was an essay test, the extent of validity was confirmed by experts' evaluations. Those experts were three lecturers who taught Islamic education; who had research interests in Islamic radicalism; and who taught Indonesian language that examined the quality of essay prompts. For reliability, the test was tried out to learners who were not engaged as the study samples. The try-out scores gained based on Huba and Freed's (2000) rubric were subsequently calculated using Alpha Cronbach formula. The result indicated that the alpha value was 0.81 higher than 0.7 . It exhibited that the test was reliable. In the end, after pretest, the provisions of CL and lecturing interventions, posttest, and delayed posttest, the impact of CL on learners' critical thinking skills was measured using paired sample t-test and independent sample t-test.

For the investigation purpose, the current study probed into learners' perspectives on CL using in-depth interviews. 9 learners, representing each category of GPAs and having experienced CL learning processes, were purposively selected to be interviewed. The results of interview were transcribed and analyzed using Miles, Huberman, and Saldana's (2014) interactive model. Anchored in this model, the data analysis ranged from data collection, data condensation, data display, to verifying conclusion. As the foregoing, the qualitative data were obtained from interviews. The data were further condensed by classifying them on the basis of some representative themes so that the data could be easily comprehended and interpreted. The data were continuously displayed by presenting some representative interview transcripts, related scientific interpretations, and scientific discussions. In the end, the data were summarized in a relevant way.

\section{FINDINGS}

The Impact of CL on Learners' Critical Thinking Skills in Addressing Islamic Radicalism

The impact of CL on learners' critical thinking skills in addressing Islamic radicalism was measured using paired sample t-test and independent sample t-test. The results of data analysis are presented in table 2 below: 
Table 2

The results of data analysis of CL's impact on critical thinking skills

\begin{tabular}{llllll}
\hline Class & Test & Mean & SD & N & Sig. \\
\hline \multirow{2}{*}{$\begin{array}{l}\text { Experimental } \\
\text { Class }\end{array}$} & Pretest & 55.5 & 21.057 & 20 & 0.000 \\
\cline { 2 - 6 } & Posttest & 78.5 & 19.787 & 20 & 0.000 \\
\cline { 2 - 6 } & Delayed posttest & 75.25 & 21.1 & 20 & 0.11 \\
\hline \multirow{2}{*}{$\begin{array}{l}\text { Control } \\
\text { Class }\end{array}$} & Pretest & 56 & 23.55 & 20 & 0.000 \\
\cline { 2 - 6 } & Posttest & 66.75 & 25.05 & 20 & 0.000 \\
\cline { 2 - 6 } & Delayed posttest & 59.75 & 26.5 & 20 & 0.000 \\
\hline
\end{tabular}

Grounded in table 2, there was a significant difference between pretest and posttest in the experimental class $(\mathrm{p}=0.000<0.05)$. A significant difference was also found between pretest and posttest in the control class $(\mathrm{p}=0.000<0.05)$. The posttest means of both classes were higher than those of pretest. The foregoing premise was proven by the data conditions depicting that the posttest means were 78.5 in the experimental class and 66.75 in the control class, and the pretest means were 55.5 in the experimental class and 56 in the control class. The data conditions as such exhibited that both CL and lecturing interventions had an impact on learners' critical thinking skills in addressing Islamic radicalism.

Subsequently, resting upon the results of independent sample t-test, there was a significant difference in posttest results between experimental and control classes $(\mathrm{p}=0.000<0.05)$. The posttest mean of the experimental class $(\mathrm{M}=78.5)$ exceeded that of the control class $(\mathrm{M}=66.75)$. The foregoing condition demonstrated that learners from the experimental class experienced a better critical thinking improvement compared to those of the control class especially in addressing Islamic radicalism. In the aspect of delayed posttest, the means were 75.25 in the experimental class and 59.75 in the control class. If compared to the posttest means, they were 78.5 in the experimental class and 66.75 in the control class. It could be seen that both classes experienced decreases in the delayed posttest scores. Nevertheless, the retention of learners' critical thinking skills in the experimental class was stronger than those of the control class. The result of paired sample t-test for the experimental class did not demonstrate any significant difference between the delayed posttest and posttest scores $(p=0.11>0.05)$. In the meantime, there was a significant difference between the delayed posttest and posttest scores in the control class $(\mathrm{p}=0.000<0.05)$. The delayed posttest mean in the experimental class was higher than that of the control class $(75.25>59.75)$. This condition proved that the learners who experienced CL interventions had much better retention of their critical thinking skills compared to those experiencing interventions in the form of lecturing.

\section{Learners' Perspectives on $\mathbf{C L}$}

The interview data seemed to have supported the experimental results. The learners who were interviewed portrayed some themes representing CL's contributions to their development in addition to their critical thinking skills. Those themes, coded based on their interview transcripts, were comprised of CL's perceived contributions to learners' 
emotional awareness, learning motivation, cognitive development, and openmindedness. The following table 3 displays the summary of data, and under the table is the presentation of some interview transcripts deliberately selected to represent the overall learners' perspectives on CL.

Table 3

The summary of data pertinent to learners' perspectives on CL

\begin{tabular}{lll}
\hline No & $\begin{array}{l}\text { Themes coded based on learners' } \\
\text { perspectives on CL }\end{array}$ & Learners \\
\hline 1 & $\begin{array}{l}\text { CL's perceived contributions to learners' } \\
\text { emotional awareness }\end{array}$ & $\begin{array}{l}\text { Participant 5; Participant 8; and } \\
\text { Participant 1 }\end{array}$ \\
\hline 2 & $\begin{array}{l}\text { CL's perceived contributions to learners' } \\
\text { learning motivation }\end{array}$ & $\begin{array}{l}\text { Participant 7; Participant 2; and } \\
\text { Participant 9 }\end{array}$ \\
\hline 3 & $\begin{array}{l}\text { CL's perceived contributions to learners' } \\
\text { cognitive development }\end{array}$ & Participant 3; and Participant 8 \\
\hline 4 & $\begin{array}{l}\text { CL's perceived contributions to learners' } \\
\text { open-mindedness }\end{array}$ & Participant 6; and Participant 4 \\
\hline
\end{tabular}

As regards emotional awareness, learners perceived that $\mathrm{CL}$ trained their patience during discussions. For instance, participant 5 said:

"CL trains me to control my emotion when I am engaged in group discussions. Sometimes, some of my friends have not yet understood about the explanations that I utter. Thus, I have to be more patient and make an effort to re-explain my points in detail. I learn how to leave aside my egotism." (Participant 5)

Participant 5's perspective was also supported by participant 8 as follows:

"CL treats me to be patient because every argument, whether it aligns with others' or not, must finally end up with a consensus." (Participant 8)

Subsequently, CL was also perceived as contributive to guiding learners to be more careful while giving arguments so that they could avoid possible misunderstandings. For example, participant 1 said:

"CL trains me to be aware and careful to argue some sensitive issues or others' opinions because it is very possible that I will mistakenly use some words or expressions that drive others' temper." (Participant 1)

To put it simply, in the aspect of emotional awareness, learners perceived that CL led them to be patient and careful while making arguments during group discussions.

The data also demonstrated that CL drove learners' motivation in learning. CL, demanding learners to keep searching for relevant information of literature addressing the discussed topic, made them feel motivated to be actively engaged into learning. With respect to this point, participant 7 said:

"I perceive that I become more motivated to be diligent in reading because the discussions we take part in are guided by interesting procedures. One of the activities in our guided discussions is to look for various literatures concerning the issue we are 
discussing. In some way, I experience many kinds of conflicts in my mind because reading scientific literatures is so challenging. However, to be honest, I like learning in this way because CL leads me to be critical and not to argue something only based on my personal opinions." (Participant 7)

As depicted in the foregoing transcript, participant 7 experienced some cognitive conflicts when he was dealing with a variety of scientific literatures, but this condition triggered his motivation to be more diligent so that he could be more knowledgeable and critical. With CL implementation, those who were not adequately active would be triggered to actively participate in CL learning processes. This point could be seen from the transcript of interview with participant 2 as follows:

"I admit that my cognitive skill is not so good especially when I have to analyze a case. However, CL activities make me feel interested in participating more actively just like others who become more diligent in reading scientific literatures to corroborate their arguments." (Participant 2)

The other learner even felt that CL made him anchored in learning even after the class had been ended. In this point, participant 9 said:

"I love learning with CL. After coming home from college, I even ended up with my curiosity about the issue I learned during CL discussions. " (Participant 9)

It could be understood that in the aspect of learning motivation, CL led learners to be more diligent, critical, and enthusiastic about learning.

In association with cognitive development, learners perceived that they found some changes in their viewpoints vis-a-vis an issue discussed. The cognitive changes as such indicated the improvement of their cognitive maturity. This condition was depicted in the selected transcript of interview with participant 3 as follows:

"Learning with CL makes me driven to keep reading scientific literatures so that I get many perspective changes concerning a discussed issue. CL makes me accustomed to arguing something based on my mature concepts. " (Participant 3)

With its merits, CL also made learners accustomed to being critical and capable of synthesizing various concepts during discussions. This condition could be seen in the following transcript of interview with participant 8 .

"I make connections between all information that I acquire from literatures and my friends' information. This process calls for my criticism and abilities to synthesize various points which can be connected, and some points which are irrelevant to one another." (Participant 8)

To sum up, as regards cognitive development, learners perceived that CL improved their cognitive abilities and maturity.

Furthermore, learners also perceived that CL made them more open-minded. It could be seen from a transcript of interview with participant 6 below: 
"I get many things. One of them is a change in my mindset. Before learning with CL, I only understood about radicalism as told by a few Muslim scholars that I preferred to update on social media without making efforts to find different viewpoints to be compared. After learning with CL and taking part in various group discussion activities involving many partners with diverse perspectives, I could see that my personal perspectives on Islamic radicalism are probably not the only correct ones. Thus, I have to be more open-minded while facing different opinions." (Participant 6)

CL seemed to be sufficiently contributive to participant 6's mindset. In a similar point, participant 4 also found that CL made her more open to various points of view for the sake of broadening her knowledge regarding an issue discussed.

"Perspective conflicts that I experienced because of different arguments during CL discussions and various viewpoints that found in literatures make me feel that I am not yet sufficiently knowledgeable about the discussed issue. This condition makes me more open to accept others' points as some comparative sources. In my opinion, learning together is indeed more effective than learning alone, and learning from many sources is more beneficial than being fanatical about one source only." (Participant 4)

In short, CL led learners to accept differences and to make those differences comparative sources in order to be more knowledgeable as well as wiser while dealing with a problem.

\section{DISCUSSION}

The experiment of the present study revealed that CL in the form of group discussions had a positive and significant impact on learners' critical thinking skills in addressing Islamic radicalism. Learners taught by using CL experienced a better critical thinking improvement compared to those taught by means of lecturing. Subsequently, learners taught by using CL had good retention of their critical thinking skills. The findings of the current study to some extent support some of the prior findings exhibited in different contexts. Those findings revealed that CL applied using various models is contributive to learners' critical thinking skills in terms of particular learning subjects (Hunaidah et al., 2018; Isnawati et al., 2020; Kusumawati et al., 2019; Saiz Sanchez et al., 2015). It could be understood that there are many ways of implementing CL, and one way is commonly selected based upon a certain learning subject. In the current study, the selected way of applying CL is by means of group discussions. This way is considered relevant because the present study makes an effort to cultivate learners' critical thinking skills in terms of solving social problems vis-a-vis Islamic radicalism in Indonesia which are brought into learning in the classrooms of Islamic education department. The effectiveness of CL based discussion has also been proven by Hajhosseini, Zandi, Shabanan, and Madani (2016). They revealed that CL in such a way supports learners' understanding in depth so that they continuously explore their thinking concepts. In this sense, interactive processes during discussions gradually train both learners' critical thinking skills and their cooperative competences.

The qualitative investigation into learners' perspectives on CL also revealed some information indicating that other than improving learners' critical thinking skills, CL 
was also contributive to learners' emotional awareness, learning motivation, cognitive development, and open-mindedness. In the aspect of emotional awareness, CL led learners to enhance their positive emotions during collaborative discussions wherein they became more patient and careful to argue a discussed topic during group work. The state of being more patient and careful to make arguments in this sense represents their regulated emotions for the sake of controlling each other's emotions during collaboration (Bakhtiar, Webster, \& Hadwin, 2017; Järvenoja, Järvelä, \& Malmberg, 2015, 2017; Järvenoja, Näykki, \& Törmänen, 2019). Their collaborative participations cultivate their positive emotions (Volet, Seghezzi, \& Ritchie, 2019). In the aspect of learning motivation, CL drove learners' motivation in order to be more diligent, critical, and enthusiastic about learning. In this regard, the current study depicted that CL adopted from Paul's (2000) learning procedures with adequate scientific learning principles (Saab, van Joolingen, \& van Hout-Wolters, 2009) potentially enhances the quality of CL discussions, and the qualified discussions established in CL promote learners' motivation in learning (Curşeu, Chappin, \& Jansen, 2018).

The other finding of the current study also indicated that learners perceived CL as one of the contributive factors promoting the development of their cognitive ability and maturity. As revealed in the present study, scientific interactions built up in collaborative discussions (e.g. during collaborative discussions, learners were making arguments based on the literature or studies they accessed from online libraries and journals, wherein such literature or studies addressed the topic they learned) stimulate the activation of their cognitive abilities which further support the success of their collaboration (Isohätälä et al., 2019; Järvenoja et al., 2019; Khosa \& Volet, 2014; Näykki, Järvelä, Kirschner, \& Järvenoja, 2014). In addition, CL with the adoption of Paul's (2000) learning procedures as implemented in the current study can guide and monitor the progress of learners' cognitive interactions (Hadwin, Järvelä, \& Miller, 2018). Subsequently, the present study also demonstrated that CL made learners more broad-minded. CL conditions learners to be cooperatively engaged in interactive communication encompassing individual diversities. According to Loes et al. (2018), a learning situation as such will enhance learners' openness to diversities. Thus, it can clearly be understood and CL is sufficiently contributive to learners' social competence in terms of broad-mindedness.

The present study contributes to literatures addressing the interrelationship of $\mathrm{CL}$, critical thinking skills, emotional awareness, learning motivation, cognitive development, and broad-minded social competence. However, this study is limited to a small number of experimental samples of only 40 learners studying a college material vis-a-vis Islamic radicalism. Of 40 learners, between 18 male and 22 female learners, there is not found any difference in critical thinking skills in terms of gender difference. This condition might be caused by the small number of samples so that critical difference in the variable of gender cannot be exclusively identified. Thus, It is recommended that further studies be conducted by involving more participants with good distribution of gender variable so that there can be learned in detail the contribution of gender diversity to the variable of critical thinking skills. 


\section{CONCLUSION}

The experimentation of this study shows that CL applied in the form of group discussions has a positive and significant impact on learners' critical thinking skills in addressing Islamic radicalism. CL also promotes the retention of their critical thinking skills. In addition, the findings of the qualitative investigation into learners' perspectives on CL also support the effectiveness of CL. The investigation depicts that CL is contributive to learners' emotional awareness, learning motivation, cognitive development, and broad-mindedness. Anchored in the findings of the present study, further studies can be oriented towards constructing a theoretical CL model which involves a couple of components such as critical thinking skills, emotional awareness, learning motivation, cognitive development, and social competence. CL model as such can subsequently be examined and confirmed so that the data revealed can be of meaningful references for those who are interested in CL.

\section{REFERENCES}

Abrami, P. C., Bernard, R. M., Borokhovski, E., Wade, A., Surkes, M. A., Tamim, R., \& Zhang, D. (2008). Instructional interventions affecting critical thinking skills and dispositions: A stage 1 Meta-Analysis. Review of Educational Research, 78(4), 11021134. https://doi.org/10.3102/0034654308326084

Ary, D., Jacobs, L. C., Sorensen, C. K., Walker, D. A., \& Razavieh, A. (2010). Introduction to research in education. Measurement (8th ed., Vol. 4). USA: Wadsworth, Cengage Learning. https://doi.org/10.1017/CBO9781107415324.004

Asay, S. M., \& Curry, B. M. (2003). Implementing and assessing a critical thinking problem solving project. Journal of Teaching in Marriage \& Family, 3(3), 375-398. https://doi.org/10.1300/J226v03n03_07

Bakhtiar, A., Webster, E. A., \& Hadwin, A. F. (2017). Regulation and socio-emotional interactions in a positive and a negative group climate. Metacognition Learning, 1-34. https://doi.org/10.1007/s11409-017-9178-X

Behr, I. Von, Reding, A., Edwards, C., \& Gribbon, L. (2013). Radicalisation in the digital era. SANTA MONICA, CA • WASHINGTON, DC: RAND Corporation.

Browne, L., Hough, M., \& Schwab, K. (2009). Scaffolding: A promising approach to fostering critical thinking. SCHOLE: A Journal of Leisure Studies and Recreation Education, 24(1), 114-119. https://doi.org/10.1080/1937156x.2009.11949630

Bruinessen, M. van. (2013). Contemporary Developments in Indonesian Islam: Explaining the Conservative Turn. Singapore: Institute of Southeast Asian Studies.

Chatterjee, R., \& Correia, A. P. (2020). Online students' attitudes toward collaborative learning and sense of community. American Journal of Distance Education, 34(1), 5368. https://doi.org/10.1080/08923647.2020.1703479

Chee, K. N., Yahaya, N., \& Ibrahim, N. H. (2018). An evaluation of the learning effectiveness of a formulated ideal social collaborative mobile learning environment 
application towards cognitive level in biology. International Journal of Mobile Learning and Organisation, 12(2), 162-189.

Creswell, J. W. (2007). Qualitative inquiry \& research design: Choosing among five approaches (2nd ed.). USA: SAGE publications, Inc.

Curşeu, P. L., Chappin, M. M. H., \& Jansen, R. J. G. (2018). Gender diversity and motivation in collaborative learning groups: the mediating role of group discussion quality. Social Psychology of Education, 21(2), 289-302. https://doi.org/10.1007/s11218-017-9419-5

Fawcett, L. M., \& Garton, A. F. (2005). The effect of peer collaboration on children's problem-solving ability. British Journal of Educational Psychology, 75(2), 157-169. https://doi.org/10.1348/000709904X23411

Fealy, G. (2004). Islamic radicalism in Indonesia: The falterning revival? Institute of Southeast Asian Studies (ISEAS), 104-121.

Giannakos, V., \& Darra, M. (2018). The implementation of Computer-Supported Collaborative Learning in Secondary Education. International Journal of Learning and Development, 8(4), 137. https://doi.org/10.5296/ijld.v8i4.13794

Hadiz, V. R. (2008). Towards a sociological understanding of Islamic radicalism in Indonesia. Journal of Contemporary Asia, 38(4), 638-647. https://doi.org/10.1080/00472330802311795

Hadwin, A. F., Järvelä, S., \& Miller, M. (2018). Self-regulation, co-regulation, and shared regulation in collaborative learning environments. In D. H. Schunk \& J. A. Greene (Eds.), Handbook of self-regulation of learning and performance (2nd ed., pp. 83-106). New York: Routledge.

Hajhosseini, M., Zandi, S., Shabanan, S. H., \& Madani, Y. (2016). Critical thinking and social interaction in active learning: A conceptual analysis of class discussion from Iranian students' perspective. Curriculum \& Teaching Studies, 1-9. https://doi.org/10.1080/2331186X.2016.1175051

Hautala, J., \& Schmidt, S. (2019). Learning across distances: an international collaborative learning project between Berlin and Turku. Journal of Geography in Higher Education, 43(2), 181-200. https://doi.org/10.1080/03098265.2019.1599331

Hei, M. S. A. De, Strijbos, J. W., Sjoer, E., \& Admiraal, W. (2015). Collaborative learning in higher education: lecturers' practices and beliefs. Research Papers in Education, 30(2), 232-247. https://doi.org/10.1080/02671522.2014.908407

Howard, L. W., Tang, T. L. P., \& Jill Austin, M. (2015). Teaching critical thinking skills: Ability, motivation, intervention, and the pygmalion effect. Journal of Business Ethics, 128(1), 133-147. https://doi.org/10.1007/s10551-014-2084-0

Huba, M. E., \& Freed, J. E. (2000). Learner-centered assessment on college campuses: Shifting the focus from teaching to learning. Boston: Allyn \& Bacon. 
Hunaidah, H., Susantini, E., Wasis, W., Prahani, B. K., \& Mahdiannur, M. A. (2018). Improving collaborative critical thinking skills of physics education students through implementation of CinQASE learning model. Journal of Physics: Conference Series, 17. https://doi.org/10.1088/1742-6596/1108/1/012101

Idris, M. M. (2020). Assessing intercultural competence (IC) of state junior high school English teachers in Yogyakarta. Indonesian Journal of Applied Linguistics, 9(3), 628636. https://doi.org/10.17509/ijal.v9i3.23213

Isnawati, Ibrahim, M., Tjandrakirana, Suyidno, Rusmansyah, \& Kusuma, A. E. (2020). The effect of collaborative based science learning model on enhancing students' critical thinking skills and responsibility. Journal of Physics: Conference Series, 1422(1). https://doi.org/10.1088/1742-6596/1422/1/012026

Isohätälä, J., Näykki, P., \& Järvelä, S. (2019). Cognitive and socio-emotional interaction in collaborative learning: exploring fluctuations in students' participation. Scandinavian Journal of Educational Research, 1-21. https://doi.org/10.1080/00313831.2019.1623310

Järvenoja, H., Järvelä, S., \& Malmberg, J. (2015). Understanding regulated learning in situative and contextual frameworks. Educational Psychologist, 50(3), 204-219. https://doi.org/10.1080/00461520.2015.1075400

Järvenoja, H., Järvelä, S., \& Malmberg, J. (2017). Supporting groups' emotion and motivation regulation during collaborative learning. Learning and Instruction, 1-11. https://doi.org/10.1016/j.learninstruc.2017.11.004

Järvenoja, H., Näykki, P., \& Törmänen, T. (2019). Emotional regulation in collaborative learning: When do higher education students activate group level regulation in the face of challenges? Studies in Higher Education, 1-11. https://doi.org/10.1080/03075079.2019.1665318

Kaendler, C., Wiedmann, M., Rummel, N., \& Spada, H. (2015). Teacher competencies for the implementation of collaborative learning in the classroom: A framework and research review. Educational Psychology Review, 27(3), 505-536. https://doi.org/10.1007/s10648-014-9288-9

Khosa, D. K., \& Volet, S. E. (2014). Productive group engagement in cognitive activity and metacognitive regulation during collaborative learning: can it explain differences in students' conceptual understanding? Metacognition and Learning, 9(3), 287-307. https://doi.org/10.1007/s11409-014-9117-z

Kirschner, P. A. (2004). Design, development, and implementation of electronic learning environments for collaborative learning. Educational Technology Research and Development, 52(3), 39-46. https://doi.org/10.1007/BF02504674

Kurniasih, R., Sujadi, I., \& Pramesti, G. (2016). The Implementation of Collaborative Learning Using AfL through Giving Feedback Strategy for Improving Students' 
Attention to Mathematics Lesson. Journal of Physics: Conference Series, 693(1). https://doi.org/10.1088/1742-6596/693/1/012018

Kusumawati, R., Hobri, \& Hadi, A. F. (2019). Implementation of integrated inquiry collaborative learning based on the lesson study for learning community to improve students' creative thinking skill. Journal of Physics: Conference Series, 1-11. https://doi.org/10.1088/1742-6596/1211/1/012097

Lee, M. Y., Kim, H., \& Kim, M. (2014). The effects of Socratic questioning on critical thinking in web-based collaborative learning. Education as Change, 18(2), 285-302. https://doi.org/10.1080/16823206.2013.849576

Leist, C. W., Woolwine, M. A., \& Bays, C. L. (2012). The effects of using a critical thinking scoring rubric to assess undergraduate students' reading skills. Journal of College Reading and Learning, 43(1), 31-58. https://doi.org/10.1080/10790195.2012.10850361

Lindsey, \& Pausacker, H. (2016). Religion, Law and Intolerance in Indonesia. London: Routledge.

Loes, C. N., An, B. P., Saichaie, K., \& Pascarella, E. T. (2017). Does Collaborative Learning Influence Persistence to the Second Year of College? Journal of Higher Education, 88(1), 62-84. https://doi.org/10.1080/00221546.2016.1243942

Loes, C. N., Culver, K. C., \& Trolian, T. L. (2018). How Collaborative Learning Enhances Students' Openness to Diversity. Journal of Higher Education, 89(6), 935960. https://doi.org/10.1080/00221546.2018.1442638

Marzano, R. J., Pickering, D., \& Pollock, J. E. (2001). Classroom instruction that works: Research-based strategies for increasing student achievement. Alexandria: ASCD. Retrieved from http://www.amazon.com/Classroom-Instruction-That-WorksResearch-Based/dp/0871205041

Menchik, J. (2016). Islam and Democracy in Indonesia: Tolerance without Liberalism. Cambridge: Cambridge University Press.

Miles, M. B., Huberman, A. M., \& Saldana, J. (2014). Qualitative data analysis: A methods sourcebook. Thousand Oaks, California 91320: SAGE Publications, Inc.

Morganna, R., Sumardi, \& Tarjana, S. S. (2020). Tertiary English students' attitudes towards intercultural language learning. Indonesian Journal of Applied Linguistics, 9(3), 657-665. https://doi.org/10.17509/ ijal.v9i3.23216

Näykki, P., Järvelä, S., Kirschner, P. A., \& Järvenoja, H. (2014). Socio-emotional conflict in collaborative learning-A process-oriented case study in a higher education context. International Journal of Educational Research, 68, 1-14. https://doi.org/10.1016/j.ijer.2014.07.001

Paul, R. (2000). An approach to teaching for critical thinking in health education. Journal of School Health, 70, 322-327. 
Paul, R., \& Elder, L. (2008). How to read a paragraph: The art of close reading (2nd ed.). Dillon Beach, CA: Foundation for Critical Thinking.

Riany, Y. E., Haslam, D., Musyafak, N., Farida, J., Ma, S., \& Sanders, M. (2018). Understanding the role of parenting in developing radical beliefs: Lessons learned from Indonesia. Security Journal. https://doi.org/10.1057/s41284-018-00162-6

Ruys, I., Van Keer, H., \& Aelterman, A. (2014). Student and novice teachers stories about collaborative learning implementation. Teachers and Teaching: Theory and Practice, 20(6), 688-703. https://doi.org/10.1080/13540602.2014.885705

Ruys, I., Van Keer Hilde, H., \& Aelterman Antonia, A. (2011). Student teachers' skills in the implementation of collaborative learning: A multilevel approach. Teaching and Teacher Education, 27(7), 1090-1100. https://doi.org/10.1016/j.tate.2011.05.005

Saab, N., van Joolingen, W. R., \& van Hout-Wolters, B. H. A. M. (2009). The relation of learners' motivation with the process of collaborative scientific discovery learning. Educational Studies, 35(2), 205-222. https://doi.org/10.1080/03055690802470357

Saiz Sanchez, C., Fernandez Rivas, S., \& Olivares Moral, S. (2015). Collaborative learning supported by rubrics improves critical thinking. Journal of the Scholarship of Teaching and Learning, 15(1), 10-19. https://doi.org/10.14434/josotl.v15i1.12905

Shah, N., \& Lewis, C. M. (2019). Amplifying and Attenuating Inequity in Collaborative Learning: Toward an Analytical Framework. Cognition and Instruction, 37(4), 423452. https://doi.org/10.1080/07370008.2019.1631825

Shi, J. H., \& Liu, L. H. (2013). Application of a dynamic collaborative learning oriented knowledge model. Applied Mechanics and Materials, 347-350, 3002-3007. https://doi.org/10.4028/www.scientific.net/AMM.347-350.3002

Sujito, Mahir Muttaqin, W., Kurniasih, N., Bakri, S., Budi Santosa, R., Hasan, M. A. K., ... Istiqomah, L. (2019). Combining subtext application technology and collaborative writing to improve EFL remedial students' writing competence with different learning style. Journal of Physics: Conference Series, 1175(1). https://doi.org/10.1088/1742$6596 / 1175 / 1 / 012230$

Sulisworo, D., \& Syarif, F. (2018). The Utilization of Open Educational Resources in the Collaborative Learning Environment to Enhance the Critical Thinking Skill. International Journal of Learning and Development, 8(1), 73. https://doi.org/10.5296/ijld.v8i1.12399

Suyanto, B., Sirry, M., \& Sugihartati, R. (2019). Pseudo-radicalism and the deradicalization of educated youth in Indonesia. Studies in Conflict and Terrorism, O(0), 1-20. https://doi.org/10.1080/1057610X.2019.1654726

Tolmie, A. K., Topping, K. J., Christie, D., Donaldson, C., Howe, C., Jessiman, E., ... Thurston, A. (2010). Social effects of collaborative learning in primary schools. Learning and Instruction, 20(3), 177-191. https://doi.org/10.1016/j.learninstruc.2009.01.005 
Ünsar, A. S., \& Engin, E. (2013). A case study to determine critical thinking skills of university students. Procedia - Social and Behavioral Sciences, 75, 563-569. https://doi.org/10.1016/j.sbspro.2013.04.061

Valdes-Vasquez, R., \& Clevenger, C. M. (2015). Piloting collaborative learning activities in a sustainable construction class. International Journal of Construction Education and Research, 11(2), 79-96. https://doi.org/10.1080/15578771.2014.990122

van Bruinessen, M. (2002). Genealogies of Islamic radicalism in post-Suharto Indonesia. South East Asia Research, 10(2), 117-154. https://doi.org/10.5367/000000002101297035

Volet, S., Seghezzi, C., \& Ritchie, S. (2019). Studies in higher education positive emotions in student-led collaborative science activities: Relating types and sources of emotions to. Studies in Higher Education, 1-13. https://doi.org/10.1080/03075079.2019.1665314

Warsah, I., Masduki, Y., Daheri, M., \& Morganna, R. (2019). Muslim Minority in Yogyakarta: Between Social Relationship and Religious Motivation. Qudus International Journal of Islamic Studies, $\quad 7(2), \quad 1-32$. https://doi.org/10.21043/qijis.v7i2.6873

Weinberger, Y., \& Shonfeld, M. (2018). Students' willingness to practice collaborative

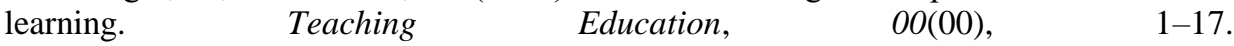
https://doi.org/10.1080/10476210.2018.1508280 